the army much beyond the age at which officers of high rank with plenty of physical and mental vigour have been compulsorily retired, cannot be denied. One thing seems pretty clear, however-viz., that the present Commander-inChief has no intention of retiring.

\section{Enteric Fever in the Army.}

We bave so frequently referred to the prevalence and mortality of typhoid fever in the army, especially in that portion of it serving in India, in connexion with water-supply and filters, that we fear our readers must be weary of the sabject; but it is one of extreme importance, and nothing should be neglected which seems likely to prevent or lessen the prevalence of this disease. There does not seem to be any doubt that the introduction of the Pasteur-Chamberland filter in the French army has been followed by a remarkable diminution in the amount of typhoid fever. The last report of the French Minister of War furnishes some very interesting and instructive information in this respect, which is altogether corroborative of the previous reports of $\mathbf{M}$. de Frepcinet on the same subject. It shows that there has been a progressive decrease in the amount of typhoid fever of late years owing to the extended use of these filters. The barrack filters in ordinary use in India are, as we have often said, worse than useless as regards the prevention of water-borne diseases, and no time should be lost, we think, in giving some trial on a large scale to the kind of filter that is used at present in the French army.

The Case of Surgeon-Major Gardner.

With reference to the case of Surgeon-Major Gardner M.B., Army Medical Staff, who joined the service in 1894 and resigned his commission under exceptionally pressing circumstances in October. 1890, we understand that the War 0fifce have decided to offer no opposition to his claim for reinstatement in Her Majesty's army, and that the motion for a reconsideration of the circumstances attending his resignation, which will be brought forward by Mr. Brynmor Jones when the Army Estimates are reached, will be supported by a number of members on both sides of the House.

\section{Indian Medical Service Examination.}

An examination for not less than twelve appointments to Her Majesty's Indian Medical Service will be held in London during the month of August next. It is notified that at this and futore examinations no candidate will be considered eligible unless, in addition to obtaining at least one-third of the marks obtainable in each compulsory subject, he shall obtain one-half the aggregate marks for all the compulsory sabjects. The exact date of the examination will be announced subsequently.

\section{SMall-pox in Calcutta.}

It would seem that the epidemic of small-pox which has been raging at Calcutta shows some signs of abatement. According to the Indian mails the number of patients at the Campell Hospital has fallen to 148 , forty-fire of whom are 㗼ropeans.

The annual dinner of the Volunteer Medical Staff of Liverpool and district was held at the Exchange Station Hotel on Wednesday evening, the 24th ult., Brigade-Surgeon-Lieutenant-Colonel Wills, V.D., being in the chair. Amongst those present were Colonel Stache, R.E., Captain Crofton, R.N., Brigade-Surgeon-Colonel Nicholson, A.M.D., FleetSurgeon White, C.B., Lieutenant-Colonel Hart, R.E., Major Thompson, R.E., and the President, Medical Institation.

The Times of India states: "Until further orders the Government of India have ruled that no Military Medical Offcer will be allowed to proceed on leave unless on medical certificate. This ruling will take effect after Yay 15th."

Nine invalids left Ceylon in the Jumna for Netley on April 1st, and twenty-five invalids were notified as leaving Sonth Africa for Netley on April 6th.

H.1I. troopship Malabar, which left Bombay on April 4th, is expected to arrive at Portsmouth on May 3rd with eightythree patients for Netley.

It has been decided by the Government $a$ : In $\mathrm{r}$ ja to allow oficers embarking direct from Rangoon for En:ope Rs. 575 as passage money.

\section{Contegandenter.}

"Audi alteram partem."

\section{"MEDICAL EVIDENCE AT INQUESTS."}

To the Editors of THE LANCET.

SIRs,-My attention has been called to an article in THE LANCET of Feb. 2nd referring to an inquest held by me on one James Powell, who shot himself through the head on Jan. 11th. The article is erroneous and I think you should not have inserted it in a valuable and important paper like yours without ascertaining whether it was true. It proves the folly of accepting as correct the statements of interested informants. In this case the medical man who had attended the deceased for many years was called in and arrived shortly after death, when he examined the wound, and his evidence as to its description and other matters was given at the inquest, and was satisfactory to the jury, myself, and the solicitor who represented the family. There was no need to cause unnecessary expense to the ratepayers by calling the other medical man at the inquest, who could only corroborate the description of the wound, whereas the one who gave evidence knew the deceased so well, and assisted the court in deciding as to the state of his mind, which was important in a case of this sort. I am, Sirs, yours faithfully,

H. MILLIGAN, Deputy Coroner.

Victoria-buildings, King-street, Wigan, Feb. 22nd, 1895.

** We willingly insert the above and regret the delay which has occurred in its publication owing to Mr. Milligan's letter having been mislaid. We still think, however, that it would have been advisable to take the evidence of the medical man who first saw the wound.-ED, L.

\section{ISOLATION AFTER DIPHTHERIA. To the Eaitors of THE LANCET.}

Sris, - Would you allow me to express a word of warning as to the risk of accepting the absence of specific bacilli (even after expert bacteriological examination) as conclusive evidence that a suspicious case of throat affection is not diphtheria? A case of undoubted diphtheria was recently notified to me. There had been no previous case in the house or vicinity, and careful inquiry failed to obtain evidence of any probable source of intection, and the patient, having recently suffered from whooping-cough, had not been out of the house for a period far exceeding the outside period of the incubation of diphtheria, bat had developed the first symptoms of that disease three days after coming in contact with her brother, who had just returned from London. His recent history was as follows. He is employed in a house of business in London, and whilst there developed a throat affection and was seen by a medical man on behalf of his employers. This gentleman considered the case suspicious and called in a second opinion, and the result of the consultation was that the patient was notified as suffering from diphtheria and forthwith removed in the ambulance to one of the metropolitan isolation hospitals, where he was injected with antitoxin. This was on March 28th, and on April 11th the patient was discharged and sent home by rail. As this was the dav preceding Good Friday the train was crowded with bolidayseekers. I have communicated with the hospital at thoritie and learn that this step was taken after a bact: riologic ${ }_{1}$ examination had given negative results as regards ti e specic bacilli of diphtheria. In conclusion, may I be allowed to st te that, on the results of etiological investigation of a $v \in X Y$ large number of outbreaks of diphtheria extending over a number of years, I have arrived at a decided opinion that in none of our ordinary severe infections diseases are we so likely to meet with cases of prolonged infection and in none is it so important to advise the longest period of isolation practicable and reasonable? I am, Sirs, yours truly,

Shropshire, April 29th, 1895. W. N. THURSFIELD, M.D. 